Feeding and flocking

\section{C.M. Lessells}

Gulls and Plovers: The Ecology and Behaviour of Mixed-Species Feeding Groups. By C.J. Barnard and D.B.A. Thompson. Croom Helm/Columbia University Press: 1985. Pp.302. £25, \$30.

THE idea that natural selection can act on an animal's behaviour, as well as its more tangible characteristics such as morphology, is well established. Behaviour is not now merely described and measured but is interpreted in terms of the selection pressures responsible for its evolution and maintenance. Barnard and Thompson follow in this tradition with their study of lapwings, golden plovers and blackheaded gulls feeding on worms in agricultural pasture.

At first sight, winter feeding and flocking behaviour are really rather mundane, but this book reveals the extent of the interdependence of feeding and flocking strategies within and between the three species: foraging choices of individuals determine the size and location of feeding flocks, while the composition of flocks in turn affects feeding rates and hence the best foraging strategies. To add to this, the black-headed gulls make their living by stealing worms from the plovers, while the plovers may exploit the gulls for early

\section{QUALITATIVE OBSERVATIONS ON RECENT FORAMINIFERAL TESTS ... \\ WITH EMPHASIS ON THE EASTERN PACIFIC PARTS \\ 1-111, 1977 - WITH EMPHASIS ON THE ATLANTIC, PART IV, 1981}

\section{by Irene A. McCulloch, PhD}

This monographic work, in preparation for more than 30 years, consists of three parts on the Pacific, totalling more than 1000 pages with 200 folio-sized plates and covering some 360 genera and 2,300 species. Part IV on the Atlantic consists of 361 pages with 72 folio-sized plates covering more than 700 taxa. The foliosized volumes are on $50 \%$ rag paper, bound in durable dark red Buksyn with gold stamped covers.

These collectors items normally sell for $\$ 200$ per set, but in honor of Dr. McCulloch's 100th Birthday we are offering them for $\mathbf{\$ 1 0 0}$ per set.

California residents add sales tax; Domestic order add \$10; Foreign add $\$ 16$ for handling.

Make checks or money orders payable in dollars to the Irene McCulloch Fund.

Mail orders to:

Allan Hancock Foundation 139

University of Southern

California, Los Angeles, CA

90089/0371. USA

BOOK REVIEWS

warning of the approach of predators.

Clearly Barnard and Thompson have set themselves quite a task in unravelling the complexities of this system. Their quantitative approach to the problem rethe book is rather hard going. Ultimately the success of the book must be judged by whether they are able to cut a path through the jungle of tables and graphs.

As in many other studies, the difficulties firstly of assessing costs and benefits of alternative actions, and secondly of reconciling the different units (such as calories and probability of predation) of costs and benefits, have made quantitative predictions rather thin on the ground. Precise quantitative predictions, however, can be made about the choice of food items by feeding plovers and thieving gulls. The "optimal diet model" provides a wellworked solution to both problems, but here it has been mangled almost beyond lies on a wealth of data, so much so that

recognition. Profitability, encounter rate, availability and prey types are all incorrectly defined; for instance equation (8.2) is akin to saying that the overall effect of driving for a while at $20 \mathrm{mph}$ and a while at $30 \mathrm{mph}$ is driving at $50 \mathrm{mph}$. Consequently the line of argument is weakest where it should be strongest. Similarly, innovative thinking elsewhere in the book is marred by inadequate explanation, confused terminology or misused statistics.

Despite this there is much interesting new detail in the book and some new ways of looking at the interrelationships of flocking and foraging strategies. Barnard and Thompson would have contributed more, however, if in their genuine attempt to push back the frontiers of darkness they had not extinguished the lights behind them.

C.M. Lessells is a Lecturer in the Department of Zoology, University of Sheffield, Sheffield S1O $2 T N, U K$.

\section{Isolated objectives}

\section{C.J. Marshall}

Molecular Cell Genetics. Edited by Michael M. Gottesman. Wiley: 1985. Pp.931. £82.30, \$79.95.

Much of the work on the genetics of cultured cells has made use of Chinese hamster cells, especially the $\mathrm{CHO}$ cell line originated by T.T. Puck, the founder of cell genetics. The importance of these cells is reflected in the emphasis of this book and it is worth noting that, as Yerganian describes, the use of Chinese hamsters is not without heroic and even tragic episodes - during the Revolution a Chinese research worker was imprisoned for his involvement in the shipment of animals to the United States

The reasons why the $\mathrm{CHO}$ cell line has been used so extensively are partly historical, but perhaps more important is the comparative ease with which recessive phenotypes can be isolated in this cell line. Siminovitch, in 1976, proposed that recessive mutations could be isolated in $\mathrm{CHO}$ cells because some loci were hemizygous as a result of chromosome rearrangements.

Subsequent studies described by Siminovitch and others have confirmed and extended these ideas. For some autosomal loci. $\mathrm{CHO}$ does appear to have only one copy of the genes; however, other loci are diploid and there is increasing evidence that one locus can be inactivated or deleted by a high frequency event $\left(10^{-3}\right.$ or greater) to uncover recessive mutations Such events may have profound implications for our understanding of alterations in gene activity that lead to neoplastic transformation.

In Molecular Cell Genetics, the editor lists over 100 mutant phenotypes in tional auxotrophic requirements, mutations in mitochondria, RNA polymerases, protein synthesis, DNA repair, lysosomes, membrane proteins, glycosylases, protein kinases and many others.

As is to be expected of a multi-authored book, the chapters in Molecular Cell Genetics are of variable quality. Some authors have written overviews of an area, often drawing very heavily on their own studies; others have provided both a review and useful hints for particular procedures. In most cases detailed experimental protocols are not provided, so this is not a laboratory manual but rather a source book which would enable one to find the appropriate protocol. Over half the chapters are concerned with particular mutant systems, while others describe features of Chinese hamster cells and methods for cell genetics such as cell fusion, gene transfer, and cloning and expression of cDNAs. Much of the work still appears to be at the stage of characterizing mutants rather than using them to dissect a particular system or probe the structural function of a protein.

For much of the book I felt that a great deal was expected of the next development: the isolation of the relevant genes. For some loci this has already been achieved; however, there is still much to be done before many of the mutant phenotypes can be exploited for what the editor terms "molecular cell genetics": the synthesis of somatic cell genetics with molecular biology.

For those working in this area, or thinking of entering it, this book will be a valulike to bear in mind, however, that there is more to cell genetics than Cricetulus griseus.

C.J. Marshall is in the Chester Beatty Laboratory, Institute for Cancer Research, 237 Fulham Road, London SW3 6JB, UK.
Chinese hamster cells which include nutriable source of information. They might 